\title{
Degree of Farm Women Participation in Sericulture Activities - A Study in Sivasagar District of Assam
}

\author{
Rekhamoni Gogoi* and Sundar Barman \\ Department of Extension Education, FA, AAU, Jorhat, India \\ *Corresponding author
}

\begin{abstract}
A B S T R A C T
The present investigation was carried out in Sivasagar district of Assam by interviewing 120 farm women selected randomly from 6 villages with an objective to assess profile characteristics and extent of participation of farm women in sericulture. Appropriate statistical was used for analysis and interpretation of data. The study revealed that middle aged farm women were associated with sericulture activities and sericulture contributed around $14 \%$ total annual family income. They practiced sericulture along with agriculture and wage earning for earning their livelihood. In case of host plant management majority of the respondents had partial participation in land preparation $(70.00 \%)$, seed sowing $(51.67 \%)$, 'plantation maintenance' $(55.00 \%)$, 'harvesting (55.00). But in case of grainage practices, it was cleared that most of the activities in case of grainage practices were performed by farm women alone. Cleaning of grainage room and equipments' (90.00\%), 'preservation of seed cocoons'(82.50\%), 'moth emergence, coupling and decoupling'(90.00\%), 'mother moth examination' $(53.33 \%)$ and 'surface sterilization of eggs' $(80.83 \%)$ were some important activities with full participation of farm women. Likewise, farm women were involved almost all activities of silk rearing like disinfection of rearing room and equipments, selection of races, season selection, incubation of eggs, black boxing, brushing of chawki worms, maintenance of larva, bed cleaning, handling of moulting larva, collection of matured worms, harvesting of cocoons In overall 62.5 percentage respondents had medium participation in agriculture activities. The concern department should be put sincere efforts for empowerment of farm women through sericulture by providing skill orientated programme to farm women along with creation of common facilities or provide small scale credit to them.
\end{abstract}

\section{Keywords}

Sericulture activities, Farm women participation in sericulture

Article Info

Accepted: 22 October 2020 Available Online: 10 November 2020

\section{Introduction}

Women are the backbone of development of any nation. In India, the females comprise $48.04 \%$ of the total population and majority of Indian females are participated in agriculture and its allied sector (anon., 2020a). The economy of India is basically based on agriculture and allied sectors. Along with agriculture, sericulture pick up as occupation by most of the rural women for their livelihood. The unique feature of sericulture activity is its egalitarianismsericulture growers rich or poor, earn the same income from it. Women play crucial role in the activities of sericulture and it 
equally creates opportunities and make them independent socially, economically, politically, and otherwise (Geetha and Indira, 2010, 2011; Pillai and Shanta, 2011; Thomas et al., 2010). In Indian condition women have been generally termed as home-makers. Women spend 16- 18 hours a day working at home and outside, but still their contribution is often unrecognized and undervalued. In fact, women have to bear double burden in the development process as they play triple role i.e. production, reproduction and community roles. Sericulture is one of the income generating activities of rural women specifically in some region and castes and tribes. It has been seen that the sericulture activity brings regular income to the community without any bias of caste, creed, gender, or religion (Kasi, 2013). Assam, a north eastern state of India has a tradition of sericulture and weaving, particularly among the rural women. Mahatma Gandhi termed Assamese women as "Weaving wizard that weaves. Assam has a unique position in the world sericulture map for production of vanya silk. The importance of silk in Indian economy is evident by the fact that 18 percent of the global raw silk is produced in India and out of that raw silk $65 \%$ eri and 95\% muga silk is produced in Assam (Annon., 2019). Considering crucial role played by farm women in sericulture activities the present study was planned to assess profile characteristics of farm women participated in sericulture activities and their degree of participation in this venture.

\section{Materials and Methods}

The present investigation was carried out in sivasagar district as it is one of the important silkworm growing districts of Assam and in Sivasagar district sericulture is practiced in large scale almost in every village from the time of ahom reign. A total of 120 farm women were selected as respondents by following simple random sampling technique from six randomly selected villages namely Dewbil napamia gaon, Dewbil boruah gaon, Lalimsinga gaon, Boraibari gaon, Pulpanisinga gaon, Belimukhia gaon. In order to assess the extent of participation of farm women in sericulture firstly the activities are divided into three heads namely host plant management, grainage technology and rearing technology and total 31 important activities were identified in sericulture. The response against each activities were recorded on a three point continuum namely, 'full participation', 'partial participation' and 'no participation' with the score of 2, 1 and 0 , respectively. Based on total obtained scores Mean ( $\bar{x}$ ) and Standard deviation (SD) were calculated and respondents were classified as follows low (below 32.72), medium (32.7254.32) and high (above 54.32). Again, activities were ranked based on weigtage mean score of each sericulture activity. Appropriate statistical tools were used for analysis and interpretation of data.

\section{Results and Discussion}

\section{Profile characteristics of farm women participated in sericulture activities}

The findings revealed that the majority of the respondents i.e. women silkworm rearers were belonged to middle age category $30-50$ years i.e. 51.67 percent, educated up to high school level (45.83\%), having joint family (60\%), medium sized family with 5-7 members $(44.17 \%)$. Most of the women sericulture rearer were married $(89.17 \%), 55 \%$ respondents were involved in sericulture + agriculture + wage earnings in case of occupation and $84.16 \%$ respondents were under the category of marginal farmer(less than $1 \mathrm{ha}$ ). In case of experience in sericulture $64.17 \%$ had medium level of experience, majority $(55.83 \%)$ of the respondents belonged to group with annual income up to 
Rs. 70,000 and out of that about $59.17 \%$ respondents earned income up to Rs. 10,000 annually from sericulture. Most of them i.e. $63.33 \%$ sericulture farmers had total host plants between 15-30 numbers. It can inferred that middle aged farm women were associated with sericulture activities and sericulture contributed around $14 \%$ total annual family income. Farm women practiced sericulture along with agriculture and other source of income for earning their livelihood (Table 1).

Table.1 Profile characteristics of farm women participated in sericulture activities $(\mathrm{N}=120)$

\begin{tabular}{|c|c|c|c|c|}
\hline \multirow{4}{*}{$\begin{array}{c}\text { Sl no } \\
1\end{array}$} & \multicolumn{2}{|c|}{ Profile characteristics of farm women } & \multirow{2}{*}{$\begin{array}{c}\text { Frequency } \\
24\end{array}$} & \multirow{2}{*}{$\begin{array}{c}\text { percentage } \\
20.00\end{array}$} \\
\hline & Age & Below 35 years & & \\
\hline & & Between $35-50$ years & 62 & 51.67 \\
\hline & & Above 50 years & 34 & 28.33 \\
\hline \multirow[t]{6}{*}{2} & \multirow{6}{*}{$\begin{array}{c}\text { Educational } \\
\text { level }\end{array}$} & Illiterate & 6 & 5.00 \\
\hline & & Upto primary level & 34 & 28.33 \\
\hline & & Upto high school level & 55 & 45.83 \\
\hline & & Upto higher secondary level & 21 & 17.50 \\
\hline & & Upto graduation level & 4 & 3.33 \\
\hline & & Upto Post graduation & 0 & 0.00 \\
\hline \multirow[t]{2}{*}{3} & \multirow{2}{*}{$\begin{array}{l}\text { Type of } \\
\text { family }\end{array}$} & Nuclear & 49 & 40.83 \\
\hline & & Joint & 71 & 59.17 \\
\hline \multirow[t]{3}{*}{4} & \multirow{3}{*}{$\begin{array}{l}\text { Size of } \\
\text { family }\end{array}$} & Small (upto 4 members) & 43 & 35.83 \\
\hline & & Medium (4-7 members) & 53 & 44.17 \\
\hline & & Large(above 7 members) & 24 & 20 \\
\hline \multirow[t]{3}{*}{5} & \multirow{3}{*}{$\begin{array}{c}\text { Marital } \\
\text { status }\end{array}$} & Single & 8 & 6.67 \\
\hline & & Married & 107 & 89.17 \\
\hline & & Widow/Divorcee & 5 & 4.17 \\
\hline \multirow{8}{*}{6} & \multirow{8}{*}{ Occupation } & Sericulture & 0 & 0.00 \\
\hline & & Seri+Agri & 31 & 25.83 \\
\hline & & Seri+Wage & 3 & 2.5 \\
\hline & & Seri+Service & 2 & 1.66 \\
\hline & & Seri+Business & 4 & 3.33 \\
\hline & & Seri+Agri+Wage & 66 & 55.00 \\
\hline & & Seri+Agri+Business & 9 & 7.5 \\
\hline & & Seri+Agri+Service & 5 & 4.16 \\
\hline \multirow{3}{*}{7} & \multirow{3}{*}{$\begin{array}{c}\text { Size of } \\
\text { operational } \\
\text { land } \\
\text { holdings }\end{array}$} & Marginal farmer & 101 & 84.16 \\
\hline & & Small farmer & 15 & 12.5 \\
\hline & & Semi medium farmer & 4 & 3.33 \\
\hline \multirow{3}{*}{8} & \multirow{3}{*}{$\begin{array}{l}\text { Experience } \\
\text { in sericulture }\end{array}$} & Low & 23 & 19.17 \\
\hline & & Medium & 77 & 64.17 \\
\hline & & High & 20 & 16.67 \\
\hline \multirow[t]{4}{*}{9} & \multirow{4}{*}{$\begin{array}{l}\text { Annual } \\
\text { family } \\
\text { income }\end{array}$} & Up to Rs 70000 & 67 & 55.83 \\
\hline & & Rs70001-150000 & 40 & 33.33 \\
\hline & & Rs $150001-300000$ & 12 & 10.00 \\
\hline & & Above Rs 300000 & 1 & 0.83 \\
\hline \multirow[t]{3}{*}{10} & \multirow{3}{*}{$\begin{array}{l}\text { Availability } \\
\text { of host plant }\end{array}$} & Less(upto 15 nos) & 11 & 9.17 \\
\hline & & Medium(15-30 nos) & 76 & 63.33 \\
\hline & & More(above 30 Nos) & 33 & 27.50 \\
\hline
\end{tabular}


Table.2 Distribution of respondents according to frequency of participation in sericulture activities $n=120$

\begin{tabular}{|c|c|c|c|c|c|c|c|}
\hline \multirow[t]{2}{*}{$\begin{array}{l}\text { Sl } \\
\text { no }\end{array}$} & \multirow[t]{2}{*}{ Category } & \multicolumn{2}{|c|}{$\begin{array}{c}\text { Full } \\
\text { participation }\end{array}$} & \multicolumn{2}{|c|}{$\begin{array}{c}\text { partial } \\
\text { Participation }\end{array}$} & \multicolumn{2}{|c|}{$\begin{array}{c}\text { No } \\
\text { Participation }\end{array}$} \\
\hline & & $\mathrm{F}$ & $\%$ & $\mathrm{~F}$ & $\%$ & $\mathrm{~F}$ & $\%$ \\
\hline $\mathbf{A}$ & \multicolumn{7}{|l|}{ Host plant management } \\
\hline 1 & Land preparation & 13 & 10.83 & 84 & 70.00 & 23 & 19.17 \\
\hline 2 & Seed collection & 29 & 24.17 & 45 & 37.50 & 46 & 38.33 \\
\hline 3 & Seed sowing & 21 & 17.50 & 62 & 51.67 & 37 & 30.83 \\
\hline 4 & Fertilizer application & 21 & 17.50 & 50 & 41.67 & 49 & 40.83 \\
\hline 5 & Weeding & 40 & 33.33 & 57 & 47.50 & 23 & 19.17 \\
\hline 6 & Prunning & 12 & 10.00 & 28 & 23.33 & 80 & 66.67 \\
\hline 7 & Pest and disease management & 35 & 29.17 & 66 & 55.00 & 19 & 15.83 \\
\hline 8 & Harvesting of leaves & 54 & 45.00 & 66 & 55.00 & 0 & 0.00 \\
\hline $\mathbf{B}$ & \multicolumn{7}{|l|}{ Grainage practices } \\
\hline 9 & $\begin{array}{l}\text { Cleaning of grainage room and } \\
\text { equipments }\end{array}$ & 108 & 90.00 & 12 & 10.00 & 0 & 0.00 \\
\hline 10 & Seed cocoon selection & 51 & 42.50 & 24 & 20.00 & 45 & 37.50 \\
\hline 11 & Seed cocoon collection and transportation & 44 & 36.67 & 28 & 23.33 & 48 & 40.00 \\
\hline 12 & Preservation of seed cocoon & 99 & 82.50 & 21 & 17.50 & 0 & 0.00 \\
\hline 13 & Coupling and decoupling of moths & 108 & 90.00 & 12 & 10.00 & 0 & 0.00 \\
\hline 14 & Examination pebrine spore in mother moth & 64 & 53.33 & 56 & 46.67 & 0 & 0.00 \\
\hline 15 & Surface sterilization of eggs & 97 & 80.83 & 23 & 19.17 & 0 & 0.00 \\
\hline 16 & Transportation of DFL & 14 & 11.67 & 29 & 24.17 & 77 & 64.17 \\
\hline $\mathbf{C}$ & Rearing practices & & & & & & \\
\hline 17 & Disinfection of rearing equipments & 106 & 88.33 & 14 & 11.67 & 0 & 0.00 \\
\hline 18 & Selection of silkworm breeds & 55 & 45.83 & 34 & 28.33 & 31 & 25.83 \\
\hline 19 & Selection of rearing season & 55 & 45.83 & 46 & 38.33 & 19 & 15.83 \\
\hline 20 & Incubation of silkworm eggs & 94 & 78.33 & 26 & 21.67 & 0 & 0.00 \\
\hline 21 & Black boxing of silkworm eggs & 93 & 77.50 & 27 & 22.50 & 0 & 0.00 \\
\hline 22 & Brushing of newly hatch silkworm & 59 & 49.17 & 51 & 42.50 & 10 & 8.33 \\
\hline 23 & Hygiene and cleaning of rearing room & 56 & 46.67 & 53 & 44.17 & 11 & 9.17 \\
\hline 24 & $\begin{array}{l}\text { Prophylactic measures against disease and } \\
\text { pest of silkworm larvae }\end{array}$ & 53 & 44.17 & 58 & 48.33 & 9 & 7.50 \\
\hline 25 & Feeding of silkworm & 50 & 41.67 & 67 & 55.83 & 3 & 2.50 \\
\hline 26 & Cleaning of silkworm bed & 103 & 85.83 & 17 & 14.17 & 0 & 0.00 \\
\hline 27 & Maintenance of spacing among silkworm & 48 & 40.00 & 49 & 40.83 & 23 & 19.17 \\
\hline 28 & Handling of moulting larvae & 73 & 60.83 & 47 & 39.17 & 0 & 0.00 \\
\hline 29 & Handling of dead silk worms & 49 & 40.83 & 63 & 52.50 & 8 & 6.67 \\
\hline 30 & Collection of matured silk worms & 84 & 70.00 & 36 & 30.00 & 0 & 0.00 \\
\hline 31 & Harvesting of cocoons & 79 & 65.83 & 41 & 34.17 & 0 & 0.00 \\
\hline 32 & Sorting of cocoon & 76 & 63.33 & 44 & 36.67 & 0 & 0.00 \\
\hline
\end{tabular}


Table.3 Distribution of respondents according to level of participation in sericulture activities $\mathrm{n}=120$

\begin{tabular}{|c|c|c|c|c|c|c|}
\hline Category & Score & F & \% & Mean & SD & CV \\
\hline Low & Below 32.72 & 24 & 20.0 & & & \\
\hline Medium & Between $32.72-54.32$ & 75 & 62.5 & 43.52 & 10.80 & 29.79 \\
\hline High & Above 54.32 & 21 & 17.5 & & & \\
\hline Total & & 120 & 100 & & & \\
\hline
\end{tabular}

Table.4 Ranking of sericulture activities according to the participation level of Farm women

$$
\mathrm{n}=120
$$

\begin{tabular}{|c|c|c|c|}
\hline Sl no & Category & $\begin{array}{l}\text { Weightage } \\
\text { mean score }\end{array}$ & Rank \\
\hline A & \multicolumn{3}{|l|}{ Host plant management } \\
\hline 1 & Land preparation & 0.92 & XXV \\
\hline 2 & Seed collection & 0.86 & XXVII \\
\hline 3 & Seed sowing & 0.87 & XXVI \\
\hline 4 & Fertilizer application & 0.77 & XXVII \\
\hline 5 & Weeding & 1.14 & XXI \\
\hline 6 & Prunning & 0.43 & XXIX \\
\hline 7 & Pest and disease management & 1.13 & XXII \\
\hline 8 & Harvesting of leaves & 1.45 & XII \\
\hline B & \multicolumn{3}{|l|}{ Grainage practices } \\
\hline 9 & Cleaning of grainage room and equipments & 1.90 & I \\
\hline 10 & Seed cocoon selection & 1.05 & XXIII \\
\hline 11 & Seed cocoon collection and transportation & 0.97 & XXIV \\
\hline 12 & Preservation of seed cocoon & 1.83 & IV \\
\hline 13 & Coupling and decoupling of moths & 1.90 & I \\
\hline 14 & Examination pebrine spore in mother moth & 1.53 & XI \\
\hline 15 & Surface sterilization of eggs & 1.81 & V \\
\hline 16 & Transportation of DFL & 0.48 & XXVIII \\
\hline $\mathbf{C}$ & \multicolumn{3}{|c|}{ REARING TECHNOLOGY } \\
\hline 17 & Disinfection of rearing equipments & 1.88 & II \\
\hline 18 & Selection of silkworm breeds & 1.20 & $\mathrm{XX}$ \\
\hline 19 & Selection of rearing season & 1.30 & XVIII \\
\hline 20 & Incubation of silkworm eggs & 1.78 & VI \\
\hline 21 & Black boxing of silkworm eggs & 1.78 & VI \\
\hline 22 & Brushing of newly hatch silkworm & 1.41 & XIII \\
\hline 23 & Hygiene and cleaning of rearing room & 1.38 & $\mathrm{XV}$ \\
\hline 24 & $\begin{array}{l}\text { Prophylactic measures against disease and pest of silkworm } \\
\text { larvae }\end{array}$ & 1.37 & $\mathrm{XVI}$ \\
\hline 25 & Feeding of silkworm & 1.39 & XIV \\
\hline 26 & Cleaning of silkworm bed & 1.86 & III \\
\hline 27 & Maintenance of spacing among silkworm & 1.21 & XIX \\
\hline 28 & Handling of moulting larvae & 1.61 & $\mathrm{X}$ \\
\hline 29 & Handling of dead silk worms & 1.34 & XVII \\
\hline 30 & Collection of matured silk worms & 1.70 & VII \\
\hline 31 & Harvesting of cocoons & 1.66 & VIII \\
\hline 32 & Sorting of cocoon & 1.63 & IX \\
\hline
\end{tabular}


Extent of participation of the farm women in different sericulture activities

The information regarding operation-wise participation of the farm women in sericulture activities is given in Table 2. Sericulture involves lots of activities beginning with the cultivation of host plants to harvesting of leaves for feeding of silkworm and the rearing of silkworm from the egg to harvesting of cocoon. In case of host plant management the data presented in Table-2 revealed that majority of the respondents had partial participation in the operations viz. land preparation $(70.00 \%)$, seed sowing $(51.67 \%)$, fertilizer application (41.67\%), pest and disease management $(55.00 \%)$, weeding $(47.50 \%)$, harvesting of leaves (55.00) while majority of the respondents had never participated in seed collection $(38.33 \%)$ and pruning operations $(66.67 \%)$. This indicates that women farmers participated in host plant cultivation as co worker with their counterpart. Social taboos may be one reason as host plant cultivation generally practiced in outside the home stead area.

In case of grainage practices, majority of the respondents had full participation in the operations viz. 'cleaning of grainage room and equipments' $(90.00 \%)$, 'preservation of seed cocoons'(82.50\%), 'moth emergence, coupling and decoupling'( $90.00 \%)$, 'mother moth examination' (53.33\%), 'surface sterilization of eggs' $(80.83 \%)$. On the other hand majority of them had never participated in 'transportation Disease Free Laying' $(64.17 \%)$ and 'Seed cocoon collection and transportation' $(40 \%)$. It can be interpreted that most of the activities in case of grainage practices were performed by farm women alone.

In case of rearing of silkworm it was cleared from the table 2 that majority of the respondents had full participation in the operations of rearing of silkworms viz. 'disinfection of rearing room and equipments'(88.33\%), 'selection of silkworm breeds' $(45.83 \%)$, 'selection of rearing season' $(45.83 \%)$, 'incubation of eggs'(78.33\%), 'black boxing' (77.50\%), 'brushing of newly hatched silkworm(49.17\%), 'bed cleaning'(85.83\%), 'handling of moulting larva' (60.83\%), 'hygiene maintenance and cleaning of rearing of rearing room' (46.67\%), 'Prophylactic measures against disease' (44.17\%), 'spacing maintenance' $(40.00 \%)$, 'collection of matured worms' $(70.00 \%)$, 'harvesting of cocoons'(65.83\%), and 'sorting of $\operatorname{cocoon}(63.33 \%)$ while majority of the respondents had partial participation in 'feeding of silkworms' (55.83?\%) and 'handling of dead worms' $(52.50 \%)$. This indicates that mostly farm women are more involved in activities of silkworm rearings.

The data with respect to overall extent of participation of the respondents in different silk rearing activities are presented in Table 3 and it is observed that a majority $(62.50 \%)$ of the respondents had medium level of participation in sericulture activities. While, 20 per cent had low and 17.5 per cent had high level of participation in agriculture activities. Similar findings were reported by Devi, et al., (2018). This may be due to that women participated in some selected practices of host plant cultivation and grainage practices. Again, in most of the outdoor activities women were participated as co workers.

\section{Ranking of activities according to their level of participation}

Ranking was done based on weightage mean score. The table 4 revealed that 'cleaning of grainage room and equipments' and 'coupling and decoupling of moths' occupied the $1^{\text {st }}$ position in ranking of activities of women 
participation. These two activities are solely performed by women. Without the help of male members of family women sericulture rearer alone can clean all the grainage equipments and grainage room before production of disease free layings. Likewise coupling and decoupling is also very important for egg laying which is also solely done by women. Then disinfection of rearing equipments occupies the $2^{\text {nd }}$ position in ranking. It is a very important activities performed by women for successful rearing. In fact, disinfection, before and after each rearing is considered the key for a successful cocoon crop. To protect from pathogens, special attention is needed for disinfection of every nook and corner of the rearing house and appliance which should be carried out on bright sunny days. The $3^{\text {rd }}$ rank was occupied by cleaning of silkworm bed. As soon as the larvae grow-up, the unconsumed leaves and litter increase in the rearing bed which ultimately favour multiplication of pathogenic organisms. Hence, timely bed cleaning is essential to keep the worms healthy which are mostly done by women. Preservation of seed cocoon and surface sterilization of eggs occupied the $4^{\text {th }}$ and $5^{\text {th }}$ rank. Cocoons are preserved in a single layer for proper aeration which is most essential for proper development of moth. Surface sterilization of eggs should be ensured to avoid contamination and it helps in removal of pathogens adhering to the egg shells and also prevents secondary contamination. Black boxing and incubation of silkworm eggs occupied the $6^{\text {th }}$ and $7^{\text {th }}$ rank. Incubation is a process in which the eggs are made to hatch under an ideal temperature, humidity, light, etc. If incubation is done the rate of hatching and the health of the young worms will be ensured; ultimately the cocoon quality and yield also will be improved. Black boxing is done by keeping the eggs under total; darkness either by wrapping them in black paper or keeping them in a black box or dark room. It is carried out to ensure the simultaneous hatching of eggs. Collection of matured silk worms was ranked in $8^{\text {th }}$ position. Before this process, the required number of mountages should be kept ready well in time. The worms should be collected carefully for mounting and all these activities are carried out mainly by women. The $9^{\text {th }}$ rank was occupied by the activity sorting of cocoon which is carried out in a dark room. It is done by women to remove the defective cocoons from healthy cocoons. Handling of moulting larva occupied $10^{\text {th }}$ position. Moulting is a very sensitive period during which the worms cast off its old skin and the body is soft and delicate. A good rearing is judged by the uniformity of the larvae entering into moulting and emerging from moulting. The brushing and feeding of the worms play key role for uniform moulting. It is important to keep the rearing bed dry when the worms are in moult. No bed cleaning should be done during moulting of silkworms. Women participation is comparatively less in case of host plant management.

In conclusion the economically poor, middle aged and marginal category of farm women were engaged in sericulture activities along with other income generating activities. The concern department should be put sincere efforts for empowerment of farm women through sericulture either in the form of common facilities creation or provide small scale credit to farm women. Farm women participate in almost all activities of sericulture. But some important activities of sericulture like cleaning of grainage room and equipments, coupling and decoupling of moths, were performed by farm women alone. So, training and other extension agency should give special emphasis on those activities while in planning of training programme or other skill oriented programme. Most of the women entrepreneurs involved in sericulture have 
minimum educational qualification, so government and sericulture department can organize effective training and development activities for them, which will ultimately reduce the problems and also enable the women entrepreneurs to overcome the obstacles.

\section{References}

Anonymous,(2020). http://statisticstimes.com/ demographics/sex -ratio-of-india.php .retrieved on 18th March, 2020.

Anonymous,(2019).

https://sericulture.assam.gov.in/howto/know-about-silk-and-itsproduction-in-assam.retrived on 2019.

Kasi, E. (2013). Role of women in sericulture and community development: A study from a South Indian village. SAGE Open, 3(3), 2158244013502984.

Devi, W., and Kayina, D.R. (2018). Extent of Women's Participation in Silk Industry in Imphal West District of
Manipur, India. International Journal of Current Microbiology and Applied Sciences, 7, 1838-1842.

Geetha, G. S., Indira, R. (2010). Women, income generation, and political capital in the silk industry in Karnataka. Gender Technology and Development, 14, 423-440.

Geetha, G. S., Indira, R. (2011). Silkworm rearing by rural women in Karnataka: A path to empowerment. Indian Journal of Gender Studies, 18, 89-102.

Pillai, M. P., Shanta, N. (2011). ICT and employment promotion among poor women: How can we make it happen? Some reflections on Kerala's experience. Indian Journal of Gender Studies, 18, 51-76.

Thomas, B. K., Muradian, R., de Groot, G., de Ruijter, A. (2010). Resilient and resourceful? A case study on how the poor cope in Kerala, India. Journal of Asian and African Studies, 45, 29-45.

\section{How to cite this article:}

Rekhamoni Gogoi and Sundar Barman. 2020. Degree of Farm Women Participation in Sericulture Activities - A Study in Sivasagar District of Assam. Int.J.Curr.Microbiol.App.Sci. 9(11): 3195-3202. doi: https://doi.org/10.20546/ijcmas.2020.911.385 